\title{
Gut microbiota-host interactions and juvenile idiopathic arthritis
}

\author{
Miika Arvonen 1,2,3, Lillemor Berntson ${ }^{4}$, Tytti Pokka ${ }^{2,3,5}$, Tuomo J Karttunen ${ }^{2,6,7}$, Paula Vähäsalo $2,3,5$ \\ and Matthew L Stoll ${ }^{8 *}$
}

\begin{abstract}
Background: Juvenile idiopathic arthritis is the most common form of chronic arthritis in children. There is mounting evidence that the microbiota may influence the disease.

Main body: Recent observations in several systemic inflammatory diseases including JIA have indicated that abnormalities in the contents of the microbiota may be factors in disease pathogenesis, while other studies in turn have shown that environmental factors impacting the composition of the microbiota, such as delivery mode and early exposure to antibiotics, affect the risk of chronic inflammatory diseases including JIA. Microbial alterations may predispose to JIA through a variety of mechanisms, including impaired immunologic development, alterations in the balances of pro- versus anti-inflammatory bacteria, and low-grade mucosal inflammation. Additional confirmatory studies of microbiota aberrations and their risk factors are needed, as well as additional mechanistic studies linking these alterations to the disease itself.

Conclusions: The microbiota may influence the risk of JIA and other systemic inflammatory conditions through a variety of mechanisms. Additional research is required to improve our understanding of the links between the microbiota and arthritis, and the treatment implications thereof.
\end{abstract}

Keywords: Juvenile arthritis, Microbiota, Antibiotics

\section{Background}

The last decade has witnessed an explosion of research into the causes and consequences of alterations in the microbiota. One condition that has recently become the subject of interest in this respect is juvenile idiopathic arthritis (JIA). JIA is a heterogeneous autoimmune disease comprising seven categories, several of which have distinctive clinical and genetic features [1]. Some of the categories are related to adult counterparts, for which there is also accumulating evidence of a role of the microbiota. In this review, we discuss the nature of the microbiota in JIA, factors that may predispose to dysbiosis, and mechanisms by which an altered microbiota might predispose to arthritis.

\footnotetext{
* Correspondence: mstoll@peds.uab.edu

${ }^{8}$ Department of Pediatrics, University of Alabama at Birmingham, CPP N

210 M, 1600 7th Avenue South, Birmingham, AL 35233, USA

Full list of author information is available at the end of the article
}

\section{Querying the microbiota}

The oldest method of identifying bacteria is culture. While this remains an important tool in clinical medicine, it is an ineffective means of identifying the contents and relative abundances of complex communities of organisms, many of which are difficult if not impossible to culture [2]. Until recently, a widely used tool consisted of amplification of the $16 \mathrm{~S}$ ribosomal DNA gene followed by gel electrophoresis. This allowed for visual assessment of differences in the contents of the microbiota, but did not itself provide information on the identity let alone the function of any of the organisms. Today, technology permits sequencing of whole communities. A detailed discussion of sequencing technologies and associated informatics tools are beyond the scope of the review and are available to the interested reader [3]. Two major sequencing technologies are in use today: amplicon-based, which typically consists of PCR amplification followed by sequencing of the $16 \mathrm{~S}$ ribosomal DNA region; and whole genome sequencing (WGS), in which every bit of microbial DNA is sequenced. 
Sequencing of the $16 \mathrm{~S}$ ribosomal DNA region takes advantage of the immense variability among bacteria contained in this one region. Compared to WGS, this approach has the advantage of lower cost and relatively easier analytic tools; in contrast, WGS can more readily identify bacteria at the species and even strain level and also provides direct functional information on the bacteria.

\section{Intestinal microbiota in JIA}

Two studies have evaluated the contents of the fecal microbiota in children with JIA. In a recent Finnish study [4], microbiome profiles of fecal samples of 30 untreated children with JIA (mostly with oligoarticular and rheumatoid factor-negative polyarticular JIA) were analysed with $16 \mathrm{~S}$ region-based sequencing profiling, and were compared to fecal samples of 27 healthy controls. The proportion of bacteria belonging to the phylum Firmicutes was significantly lower in children with JIA compared to controls, with a compensatory increase in the Bacteroidetes phylum. At the genus level, increased Bacteroides was observed among the children with JIA. Similar abnormalities have also been reported in children with or at risk for type 1 diabetes mellitus [5-7]

A similar, albeit not statistically significant (21\% versus $11 \%, P=0.150$ ) increase in the Bacteroides genus was also observed in the feces of a cohort of 25 children with enthesitis-related arthritis (ERA) as compared to 13 healthy control subjects [8]. This study also showed elevated levels of Akkermansia muciniphila in a subset of patients, but none of the controls [8]. In contrast, levels of Faecalibacterium prausnitzii were reduced in the ERA patients. This latter finding is consistent with observations in both pediatric and adult inflammatory bowel disease (IBD) [9].

\section{Contribution of perinatal factors in the gut microbiome}

Genetic and environmental factors influence the development of the microbiota. A discussion of the genetic factors is beyond the scope of this review, which is geared towards potentially modifiable influences. Among those, early life factors such as mode of delivery, lactation and early exposure to antibiotics influence the type of bacteria colonizing intestinal mucosa and maturation of mucosal immunity [10-12]. Vaginal delivery promotes the infant gut to colonize with Bifidobacteria, which is associated with stimulation of tolerogenic immune responses $[13,14]$. In contrast, infants delivered by Csection harbour bacterial communities found on the mother's skin surface such as Staphylococcus, Corynebacterium, and Propionibacterium spp, and higher counts of IgA, IgG, IgM secreting cells during first year of life [15-17]. Interestingly, C-section delivery is associated with an increased risk of development of multiple chronic inflammatory conditions, including food allergy, inflammatory bowel disease, type 1 diabetes and JIA [18-20].

Another perinatal variable that influences the microbiota is mode of feeding. As with mode of delivery, several observational studies have demonstrated alterations in the fecal microbiota of children bottle-fed compared to those who are nursed. Just as vaginally born infants have higher Bifidobacterium as compared to C-sectioned infants, nursed infants appear to have higher abundance of the same species, as well as increased abundance of Lactobacilli and Streptococci, two normal components of the infant fecal microbiota [21]. There is some data indicating that bottle feeding is associated with an increased risk of autoimmune disease like ankylosing spondylitis [22] and type 1 diabetes [23]. Similarly, breast-feeding appears to be protective against JIA, as evidenced by either increased likelihood or duration of breast-feeding among JIA children compared to controls [24-26].

\section{Antibiotic use, microbiome alteration and risk of JIA}

Another environmental influence on the microbiota is antibiotic usage. That antibiotics have a short-term effect on the contents of the microbiota is self-evident. $\mathrm{Nu}$ merous studies have evaluated whether this effect is sustained over time (Table 1.). The methods of assessment of the faecal samples were variable including culture, gel electrophoresis, and amplification followed by sequencing of $16 \mathrm{~S}$ ribosomal DNA, tools which as discussed above have increasing sensitivity in respective order to identify the complexity of bacterial organisms present in a sample. It appears that in many instances antibiotics do indeed affect the microbiota long-term, even up to two years in one study [27]. To some extent, it appears that antibiotics that target anaerobic organisms were more likely than others to have a lasting impact. However, ciprofloxacin did as well, particularly when patients were exposed to multiple courses [28]. In addition, a cross-sectional study in children indicated that prior exposure to macrolide antibiotics had substantial and long-lasting effects on the microbiota [29].

Two registry-based case controls studies have evaluated whether antibiotic use affects subsequent risk of JIA. Horton et al. [30] identified medical records from a database of 550 general practices in the United Kingdom, identifying 152 children with JIA and 1520 matched controls. Arvonen et al. (2015) collected data from three Finnish national registers to identify 1298 children with JIA and 5179 matched controls [31]. Both studies found a significant association between antibiotic use and subsequent JIA (Table 2), both also reporting a dose-dependent relationship; the Finnish registry as well 
Table 1 Summary of human studies evaluating long-term changes to the microbiota following exposure to antibiotics

\begin{tabular}{|c|c|c|c|c|c|c|c|}
\hline Study & Antibiotic & $\begin{array}{l}\text { Patient } \\
\text { population }\end{array}$ & $\begin{array}{l}\text { Comparison } \\
\text { Group }\end{array}$ & Habitat & $\begin{array}{l}\text { Method of } \\
\text { assessment }\end{array}$ & $\begin{array}{l}\text { Duration } \\
\text { of follow- } \\
\text { up }\end{array}$ & Results \\
\hline $\begin{array}{l}\text { De la } \\
\text { Cochetiere } \\
\text { (2005) } \\
{[72]}\end{array}$ & $\begin{array}{l}\text { Amoxicillin } x \\
5 \text { days }\end{array}$ & 6 adults & None & Feces & $\begin{array}{l}\text { TTGE of } 16 S \\
\text { rDNA } \\
\text { amplicons }\end{array}$ & $\begin{array}{l}\text { Two } \\
\text { months }\end{array}$ & $\begin{array}{l}\text { After two months, profiles were }>90 \% \text { similar } \\
\text { to baseline in } 5 / 6 \text { subjects. }\end{array}$ \\
\hline $\begin{array}{l}\text { Dethlefsen } \\
2011[28]\end{array}$ & $\begin{array}{l}\text { Two courses of } \\
\text { ciprofloxacin } x \\
5 \text { days }\end{array}$ & 3 adults & None & Feces & $\begin{array}{l}\text { Sequencing of } \\
16 S \text { rDNA }\end{array}$ & 10 months & $\begin{array}{l}\text { Altered community composition in } 3 / 3 \text {, } \\
\text { although there was more variability between } \\
\text { subjects vs before and after abx. }\end{array}$ \\
\hline $\begin{array}{l}\text { Dethlefsen } \\
2008 \text { [73] }\end{array}$ & $\begin{array}{l}\text { One course of } \\
\text { ciprofloxacin } x \\
5 \text { days }\end{array}$ & 3 adults & None & Feces & $\begin{array}{l}\text { Sequencing of } \\
16 S \text { rDNA }\end{array}$ & 30 days & $\begin{array}{l}\text { Samples returned to baseline at the } \\
\text { community level after } 30 \text { days, although } \\
\text { individual taxa failed to recover. }\end{array}$ \\
\hline $\begin{array}{l}\text { Fouhy } \\
2012^{\mathrm{a}}[74]\end{array}$ & $\begin{array}{l}\text { One course of } \\
\text { ampicillin and } \\
\text { gentamycin }\end{array}$ & $\begin{array}{l}9 \text { full-term } \\
\text { neonates } \\
\text { under age } \\
2 \text { days }\end{array}$ & $\begin{array}{l}9 \text { full-term } \\
\text { neonates }\end{array}$ & Feces & $\begin{array}{l}\text { Sequencing of } \\
16 \mathrm{~S} \text { rDNA }\end{array}$ & 8 weeks & $\begin{array}{l}\text { Decreased evenness and richness; alterations } \\
\text { in multiple genera. Of note, } 9 / 9 \text { controls but } \\
\text { only } 4 / 9 \text { patients were delivered vaginally }\end{array}$ \\
\hline $\begin{array}{l}\text { Jakobsson } \\
2010[75]\end{array}$ & $\begin{array}{l}\text { One course of } \\
\text { metronidazole and } \\
\text { clarithromycin } x \\
7 \text { days }\end{array}$ & 3 adults & 3 adults & $\begin{array}{l}\text { Throat } \\
\text { and } \\
\text { feces }\end{array}$ & $\begin{array}{l}\text { Sequencing of } \\
16 S \text { rDNA and } \\
\text { T-RFLP }\end{array}$ & 4 years & $\begin{array}{l}\text { General recovery of loss of diversity in both } \\
\text { habitats. However, long-lasting effects at the } \\
\text { taxonomic level were seen, particularly in the } \\
\text { throat. }\end{array}$ \\
\hline $\begin{array}{l}\text { Jernberg } \\
2007[27]\end{array}$ & $\begin{array}{l}\text { One course of } \\
\text { clindamycin } x \\
7 \text { days }\end{array}$ & 4 adults & 4 adults & Feces & $\begin{array}{l}\text { T-RFLP and } \\
\text { rep-PCR on } \\
\text { Bacteroides }\end{array}$ & 2 years & $\begin{array}{l}\text { Decreased number of bacteroides clonal types } \\
\text { in exposed subjects }\end{array}$ \\
\hline $\begin{array}{l}\text { Lode } \\
2001^{\mathrm{b}}[76]\end{array}$ & Linezolid $\times 7$ days & 12 adults & None & Feces & $\begin{array}{l}\text { Culture and } \\
\text { identification }\end{array}$ & 35 days & No lasting effect \\
\hline $\begin{array}{l}\text { Lode } \\
2001^{\mathrm{b}}[76]\end{array}$ & $\begin{array}{l}\text { Amoxicillin / clav } x \\
7 \text { days }\end{array}$ & 12 adults & None & Feces & $\begin{array}{l}\text { Culture and } \\
\text { identification }\end{array}$ & 35 days & No lasting effect \\
\hline $\begin{array}{l}\text { Mangin } \\
2012[77]\end{array}$ & $\begin{array}{l}\text { Amoxicillin / clav } x \\
5 \text { days }\end{array}$ & $\begin{array}{l}18 \text { adult } \\
\text { men }\end{array}$ & None & Feces & $\begin{array}{l}\text { qPCR for } \\
\text { Bifidobacterium } \\
\text { and PCR-TTGE }\end{array}$ & 64 days & $\begin{array}{l}\text { No difference in total bifidobacteria; however, } \\
\text { similarity to baseline dropped to } 50 \% \text { rapidly } \\
\text { and never reached } 60 \% \text {. }\end{array}$ \\
\hline $\begin{array}{l}\text { Savino } \\
2011[78]\end{array}$ & $\begin{array}{l}\text { Ceftriaxone } x \\
5 \text { days }\end{array}$ & $\begin{array}{l}26 \text { full-term } \\
\text { breast-fed } \\
\text { infants }\end{array}$ & None & Feces & Culture & 20 days & $\begin{array}{l}\text { No changes noted in counts of } \\
\text { enterobacteriaceae, enterococci, lactobacilli, or } \\
\text { total bacteria }\end{array}$ \\
\hline $\begin{array}{l}\text { Vervoort } \\
2015^{C}[79]\end{array}$ & $\begin{array}{l}\text { Nitrofurantoin } \times 3 \\
-15 \text { days }\end{array}$ & $\begin{array}{l}\text { Five or eight } \\
\text { subjects }\end{array}$ & $\begin{array}{l}\text { Four or five } \\
\text { subjects }\end{array}$ & Feces & $\begin{array}{l}\text { Sequencing of } \\
16 S \text { rDNA }\end{array}$ & 28 days & $\begin{array}{l}\text { Only transient differences in the frequency of } \\
\text { the phyla. }\end{array}$ \\
\hline
\end{tabular}

${ }^{\mathrm{a}}$ The duration of treatment was not specified. ${ }^{\mathrm{b}}$ This Lode study was a crossover design with a 35 days washout, in which half received amoxicillin / clavulonic acid first and the other half received linezolid first. 'The methods said five pts and four controls, but the table said 8 and 5 , respectively. No information on the age or sex of the subjects. Abbreviations: $q P C R$ quantitative $P C R, r D N A$ ribosomal DNA, rep-PCR repetitive sequence-based PCR, $R F L P$ restriction fragment length polymorphisms, $T$ $R F L P$ terminal restriction fragment length polymorphism, TTGE temporal temperature gradient gel electrophoresis

Table 2 Characteristics of the material and results in studies on exposure to antibiotics and risk of juvenile idiopathic arthritis by Horton et al. [30] and Arvonen et al. [31]

\begin{tabular}{|c|c|c|c|c|}
\hline \multirow[b]{4}{*}{ Risk of later development of JIA after exposure to } & \multicolumn{2}{|l|}{ Horton et al. } & \multicolumn{2}{|l|}{ Arvonen et al. } \\
\hline & \multicolumn{2}{|c|}{ United Kingdom } & \multicolumn{2}{|l|}{ Finland } \\
\hline & \multicolumn{2}{|c|}{ Cases $=152$, Controls $=1520$} & \multicolumn{2}{|c|}{ Cases $=1298$, Controls $=5179$} \\
\hline & $\mathrm{OR}(95 \% \mathrm{Cl})^{\mathrm{a}}$ & $P$ & $\mathrm{OR}(95 \% \mathrm{Cl})^{\mathrm{b}}$ & $P$ \\
\hline Any antibiotics & $2.1(1.2$ to 3.5$)$ & 0.007 & $1.6(1.3$ to 1.9$)$ & $<0.001$ \\
\hline Anaerobic antibiotics only ${ }^{c}$ & $1.6(1.0$ to 2.6$)$ & 0.040 & $1.3(1.04$ to 1.7$)$ & 0.021 \\
\hline Non-anti-anaerobic onlyc & $1.6(1.1$ to 2.3$)$ & 0.009 & $1.2(0.9$ to 1.7$)$ & 0.216 \\
\hline Both non-anti-anaerobic and anti-anaerobic antibiotics ${ }^{c}$ & NA & NA & $1.4(1.1$ to 1.8$)$ & $<0.001$ \\
\hline Dose response & yes & & yes & \\
\hline
\end{tabular}

${ }^{a}$ Models adjusted for matching, any infection, and any personal autoimmune disease (AID)

${ }^{\mathrm{b}}$ Model adjusted for the number of antiobiotic regiments before index day

${ }^{\mathrm{C}}$ For this analysis, anti-anaerobic antibiotics were broad spectrum penicillins, clindamycin, metronidazole, and tetracyclines (including doxycycline); aerobic antibiotics were cephalosporins, levaquines, macrolides, and sulfonamides 
showed that early exposure $(<24$ mos $)$ was associated with risk of developing JIA (OR 1.4, $95 \%$ CI 1.2-1.6). The UK study also found that this relationship held even after adjusting for infections; this was not addressed in the Finnish register-based study. The two studies did differ with respect to one critical finding: whether the antibiotics differ in their association with JIA. The UK study grouped antibiotics into those with versus without anaerobic coverage (Table 2), finding that exposure to both categories had a similar effect on the risk of subsequent JIA. The rationale for such a grouping is that the vast majority of enteric organisms are either facultative or obligate anaerobes, and as noted above, antibiotics with primarily anaerobic coverage appear to have a longer-lasting effect on the gut microbiota as opposed to antibiotics that primarily target aerobic organisms. Although not initially published in the Finnish study, we performed for the purposes of this a review conditional regression analysis of the previously published data using the same definition of anaerobic antibiotics used in the UK study. After adjustment for total number of courses of antibiotics, children exposed only to aerobic antibiotics had a non-significantly increased risk $(\mathrm{OR}=1.2, p=0.122)$, while those exposed to only anti-anaerobic antibiotics had a significantly increased risk ( $\mathrm{OR}=1.3, p=0.021$ ), and those exposed to both categories had the highest risk ( $\mathrm{OR}=1.4, p=0.003)$. That is, children exposed to a variety of different antibiotic categories appear to be at higher risk than those exposed to a more limited repertoire of antibiotics, even after adjusting for total number of courses, suggesting that the greater the overall perturbation of the microbiota, the greater the risk of JIA.

\section{Mechanisms by which the microbiota might predispose to JIA}

Dysbiosis: excessive "bad" or insufficient "good" bacteria The most straightforward explanation by which the microbiota might predispose to JIA pertains to its contents. Although true pathogens are infrequently identified in most $16 \mathrm{~S}$ studies performed in developed nations, certain bacteria appear to have the capacity to promote an inflammatory process, while others appear to be protective. For example, Scher and colleagues identified abundant Prevotella copri in many newly diagnosed rheumatoid arthritis (RA) patients, demonstrating as well that this bacteria could directly trigger inflammatory responses in mice [32]. Conversely, as noted above, Stoll and colleagues reported decreased abundance of $F$. prausnitzii in children with ERA [8]. This particular species is generally considered to have anti-inflammatory effects through production of short-chain fatty acids (SCFAs) such as butyrate [33] or by direct effects on cytokine production [34]. SCFAs serve as major sources of energy for the intestinal enterocytes and also regulate the differentiation of $\mathrm{T}$ cells, promoting a regulatory phenotype [35, 36]. Additionally, as noted above, both $16 \mathrm{~S}$ studies of children with JIA demonstrated increased Bacteroides genus in children with JIA compared to controls. The potential for this genus to demonstrate pathogenicity in arthritis was illustrated by animal models of arthritis, in which the disease is abrogated in the germfree state but present upon re-introduction of Bacteroides genus [37, 38]. Thus, certain bacteria can have direct inflammatory or anti-inflammatory effects promoting or inhibiting the development of inflammatory disease.

There is, however, limited direct evidence in JIA that the microbiota is directly responsible, or that changes in the microbiota can affect changes in the disease. Zhang et al. (2015) identified differences in the oral and gut microbiota in treatment-naïve RA patients, finding as well partial normalization following induction of disease-modifying therapy as well as pre-treatment differences in good versus poor responders to therapy [39]. This has not been studied comprehensively in children with JIA. Berntson et al. reported on a child with polyarticular JIA refractory to multiple medicines, in whom a beneficial clinical response to exclusive enteral nutrition was accompanied by elevation of Firmicutes/Bacteroidetes ratio during the treatment, although the microbiota changes were not conclusively demonstrated to be responsible for the clinical improvement [40]. Interestingly, in some other autoimmune diseases, correlation of microbiome composition and clinical course have been documented. A study of children at risk for type 1 diabetes showed that changes in the composition and diversity of the microbiota preceded development of clinical disease [7]. Likewise, a study of pediatric IBD patients revealed that disease activity was associated with reduced microbial richness, abundance of butyrate producers, and relative abundance of Gram-positive bacteria [41].

Importantly, bacteria need not be the only type of microorganism that can affect immune responses and autoimmune diseases; helminths may also modify intestinal microbiome homeostasis [42]. In addition, helminth colonization and molecules from helminths have been demonstrated to trigger regulatory pathways and attenuate the course of experimental arthritis [43]. Helminths have even been studied as a novel treatment approach for IBD [44]

\section{Immune programming}

A second mechanism by which the microbiota could impact the risk of inflammatory disease may pertain to the ontogeny of the microbiota, rather than its nature in the mature state. A dramatic illustration of this possibility comes from studies of germ-free animals, in which the 
small intestinal mucosal immune system fails to develop properly. For example germ free mice develop fewer Peyer's patches, germinal centers and lymphoid follicles in small intestinal mucosa and express reduced numbers of Th17 cells in small intestinal lamina propria [45]. Moreover, there may be a critical window of time during which the proper microbiota must be present for optimal immunologic development, as recently proposed by Blumberg and colleagues [46]. This possibility was reported by Cahenzli et al. (2013), who confirmed previous findings of elevated IgE levels in germ-free mice [47], a murine counterpart to the hypothesis that today's cleaner environments may be associated with the increased incidence of autoimmune conditions such as atopy and IBD [48]. A key finding in the study by Cahenzli was that mice exposed to normal microbiota prior to 35 days of life had normal IgE levels, while those whose exposure took place beyond that point had high levels. Similarly, colonization of young, but not old, germ-free mice with a normal microbiota abrogated the accumulation of invariant natural killer $\mathrm{T}$ cells in the colonic lamina propria and lung [49]. This concept of a window of opportunity may also explain why Bacteroides appears to be associated with autoimmunity in young $[4,7,50]$, but not adult $[32,51]$, subjects; Vatanen et al. [52] proposed that the lipopolysaccharide (LPS) tail of Bacteroides is less immunostimulatory as compared to the LPS tail of bacteria such as E. coli, and that early exposure to Bacteroides in countries such as Finland predisposes to autoimmunity due to excessive innate immune tolerance towards LPS in general. Thus, it is plausible that antibiotics in young children, in whom the microbiota is undergoing rapid changes to a more mature state, would have longer lasting effects on both the contents of the microbiota as well as subsequent immunologic function, as compared to antibiotic exposure in older children or adults. If so, this underscores the necessity of avoiding unnecessary usage of antibiotics.

\section{Aberrant microbe-specific systemic immune responses in JIA}

A given bacterial species need not be present in abnormal quantities to cause problems; it may also lead to inflammation by being a target of the immune system. Antibodies against flagellated bacteria are associated with and poor prognostic factors for Crohn's Disease [53]. There is also contradictory evidence as to whether these antibodies are associated with spondyloarthritis [50].

Pediatric patients may have different immunologic targets. Stoll et al. demonstrated that in children with ERA [8], serum IgA against B. fragilis was directly proportional to fecal Bacteroides abundance, while controls had the opposite relationship, which they took to indicate that patients had a more pathogenic response against this organism. Additionally, Singh et al. (2011) demonstrated increased $\mathrm{T}$ cell responses to the Salmonella outer membrane protein in ERA patients compared to controls [54].

These findings of aberrant immunity to intestinal or commensal organisms are not necessarily limited to children with ERA. Children with Cyclic Citrullinated Peptide (CCP) antibody positive, as compared to negative, JIA demonstrated elevated levels of antibodies against Porphyromonas gingivalis, Prevotella intermedia, and Fusobacterium. This study also showed an association between high anti-bacterial antibodies levels and clinical symptoms of gingival irritation [55]. These data are generally consistent with studies in the adult counterpart, RA [56]. The presence of antibodies directed against specific microbial agents does not necessarily indicate that the antibodies themselves are pathogenic. Antibodies reflect activity of $T_{h}$ cells, which may themselves be the pathogenic cells. This appears to be the case in IBD, where adoptive transfer of flagellin-specific CD4+ $\mathrm{T}$ cells into immunodeficient mice results in colitis [57]. Similarly, disease in the HLA-B27 transgenic rat model requires the presence of a thymus [58]; while the nature of any antigens in this model are not known, the absence of disease in the germ-free state suggests the possibility of microbial antigens [59]. The causes of such aberrant immunity as well as the mechanisms by which microbe-specific immunity may contribute to JIA are ripe for further exploration.

\section{Local immune responses and mucosal integrity in JIA}

The intestinal microbiota may also have local effects on mucosal integrity and intestinal immunity. The intestinal mucosa limits access of gut bacteria to the lymphoid tissues, thereby preventing dysregulated activation of the local innate and adaptive immune system [60]. As discussed above, increased Bacteroides and Akkermansia muciniphila have been reported in children with JIA; increased abundance of Bacteroides has also been observed in children with type 1 diabetes $[5,6]$, as well as in animal models of spodyloarthritis [61, 62]. Multiple species in the Bacteroides genus, as well as Akkermansia Muciniphila, degrade mucin [63, 64], an important component of primary mucosal defense (Fig. 1). It is plausible that mucin degradation can increase access of the bacteria to the intestinal immune system, promoting an inflammatory process, as proposed by Tailford and colleagues [65]. Along those lines, increased intestinal permeability has been identified both in children with JIA [45] and in adults with ankylosing spondylitis [66].

Intestinal inflammation in children with JIA has been evaluated mostly in the ERA category. Studies of unselected children with ERA have demonstrated increased intestinal inflammation by colonoscopy [75], leukocyte 


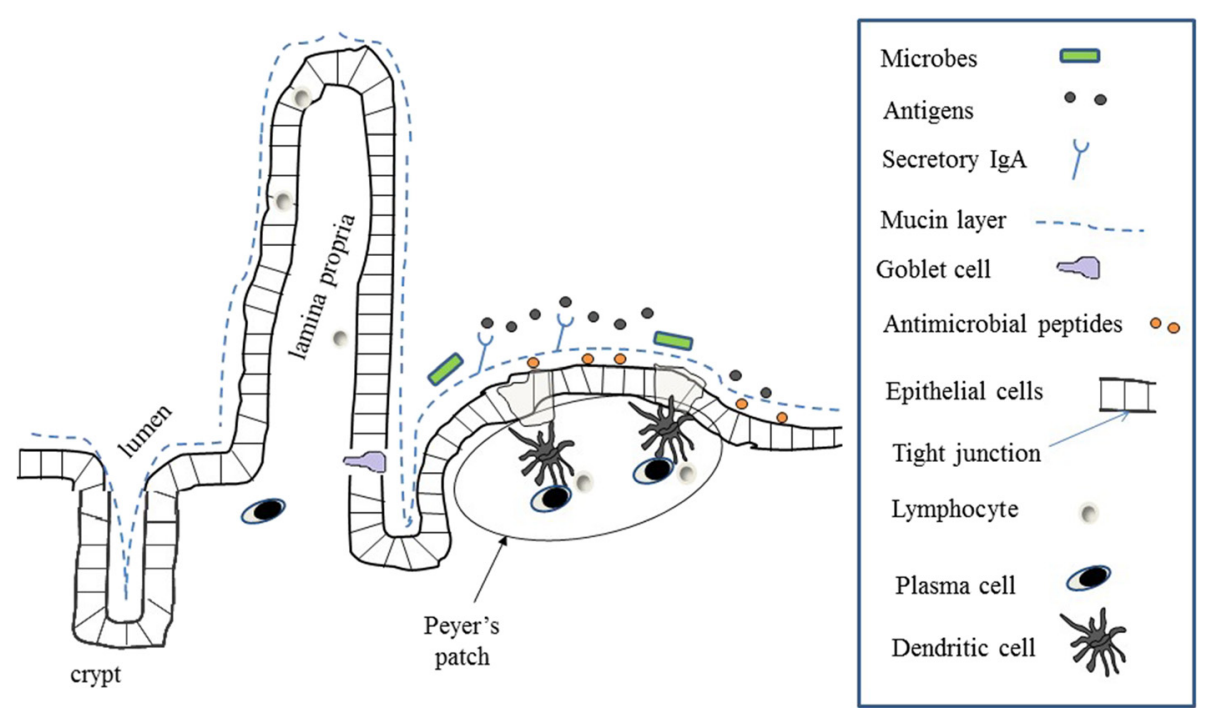

Fig. 1 The structure of intestinal mucosal defense and antigen sampling. Primary defense against penetration by luminal microbes is primarily provided by secretory IgA, mucin and antimicrobial peptides. In addition, single layered intestinal epithelial cell are anchored to each other by tight junctions. Goblet cells scattered among the epithelial lining produce mucin, which represents a physical barrier against bacterial access to epithelial cells. Secretory IgA attaches to luminal antigens and protects against invasion of pathogens inhibiting the penetration of harmful antigens. On the epithelial side of the mucin layer, antimicrobial peptides neutralize bacteria that have penetrated through the mucin layer. The Peyer's patch also contains a specific type of enterocytes, M-cells, which periodically sample the luminal contents, transcytosing luminal antigens. Antigens that have broken through the epithelial barrier to the basolateral lamina propria generate inflammatory responses, while those presented to Peyer's patches by periodic sampling typically generate regulatory responses [80,81]. Additionally, T cells activated in mesenteric lymph nodes (not shown) express intestinal homing receptors such as the integrin a4 $\beta 7$, which guide the T cells back to the intestinal mucosa, where they can participate in protective or inflammatory immune responses.

scintigraphy [76], and fecal calprotectin [67]. Children with oligoarticular and polyarticular JIA may also have intestinal immune dysregulation, although studies are limited to children with gastrointestinal complaints. Specifically, Arvonen and colleagues reported "low grade" intestinal mucosal alterations such as increased numbers of small intestinal intraepithelial $\gamma \delta+$ T cells and cytotoxic lymphocytes, and increased HLA-DR expression in ileal mucosa [68-70], the latter correlating with measures of JIA disease activity. Pichler et al. (2016) also identified increased eosinophilic gastrointestinal infiltrations in a cohort of JIA patients with gastrointestinal symptoms [71] increased eosinophilic gastrointestinal infiltrations. Thus, it is possible that abnormalities in mucosal immunity is a widespread phenomenon in children with JIA. However, some of these findings have not directly been linked to the microbiota.

\section{Conclusions}

Children with multiple categories of JIA have an altered intestinal microbiota, with the characteristics of microbiota sharing some features linked with other autoimmune diseases such as type 1 diabetes $[5,6]$ and IBD [9]. In addition, the immunologic responses to the microbiota are altered in at least ERA and RF+ JIA, and aberrant intestinal immunity appears to be present in multiple JIA categories. Several of the identified risk factors of JIA, including antibiotic use, C-section delivery, and possibly infant feeding practice, may all exert their role via alterations in the intestinal microbiota, potentially at a critical window of mucosal immunologic development. In the future, the role of immune regulatory function of helminths should also be studied, since they can attenuate the course of experimental arthritis [43]. As we learn more about factors that influence the development of the microbiota as well as the mechanisms by which the microbiota might contribute to inflammation, we may develop novel tools to prevent or even treat JIA.

\section{Abbreviations}

ERA, enthesitis-related arthritis; IBD, inflammatory bowel disease; JIA, juvenile idiopathic arthritis; RA, rheumatoid arthritis; RF, rheumatoid factor; SCFAs, short-chain fatty acids

\section{Acknowledgements}

Not applicable

\section{Funding}

Not applicable.

\section{Availability of data and materials}

We are unable to share the raw data used for these analyses. The Finnish authors Arvonen, Vähäsalo and Pokka obtained permission from the Social Insurance Institution of Finland (SII) to get encrypted data from the reimbursement register and prescpription register maintained by SII for this investigational purpose. The agreement with SII did not permit sharing of the data. 


\section{Authors' contributions}

Miika Arvonen, Lillemor Berntson, Tuomo Karttunen, Paula Vähäsalo and Matthew Stoll have participated in the drafting, writing, and revising the review. Tytti Pokka has contributed to the reanalysis and interpretation of data of the review. All authors read and approved the final manuscript.

\section{Competing interests}

The authors declare that they have no competing interests

\section{Consent for publication}

Not applicable.

\section{Ethics approval and consent to participate}

Re-analysis of data published previously [31] was performed for this review. According to the Finnish legislation, neither ethical approval nor informed consent was necessary for this or the prior publication, as we used only encrypted register data and did not contact the unidentifiable study subjects (Personal Data Act 523/1999).

\section{Author details}

${ }^{1}$ Department of Pediatrics, Kuopio University Hospital, Kuopio, Finland. ${ }^{2}$ Medical Research Center, Oulu University Hospital and University of Oulu, Oulu, Finland. ${ }^{3}$ PEDEGO Research Unit, University of Oulu, Oulu, Finland. ${ }^{4}$ Department of Women's and Children's Health, Uppsala University, Uppsala, Sweden. ${ }^{5}$ Department of Children and Adolescents, Oulu University Hospital, Oulu, Finland. ${ }^{6} \mathrm{Cancer}$ and Translational Medicine Research Unit, University of Oulu, Oulu, Finland. 'Department of Pathology, Oulu University Hospital, Oulu, Finland. ${ }^{8}$ Department of Pediatrics, University of Alabama at Birmingham, CPP N 210 M, 1600 7th Avenue South, Birmingham, AL 35233, USA.

Received: 21 May 2016 Accepted: 14 July 2016

Published online: 22 July 2016

\section{References}

1. Petty RE, Southwood TR, Manners P, Baum J, Glass DN, Goldenberg J, et al. International league of associations for rheumatology classification of juvenile idiopathic arthritis: second revision, Edmonton, 2001. J Rheumatol. 2004;31(2):390-2.

2. Langendijk PS, Schut F, Jansen GJ, Raangs GC, Kamphuis GR, Wilkinson MH, et al. Quantitative fluorescence in situ hybridization of Bifidobacterium spp. with genus-specific 165 rRNA-targeted probes and its application in fecal samples. Appl Environ Microbiol. 1995;61 (8):3069-75.

3. Franzosa EA, Hsu T, Sirota-Madi A, Shafquat A, Abu-Ali G, Morgan XC, et al. Sequencing and beyond: integrating molecular 'omics' for microbial community profiling. Nat Rev Microbiol. 2015;13(6):360-72.

4. Tejesvi MV, Arvonen M, Kangas SM, Keskitalo PL, Pirttila AM, Karttunen TJ, et al. Faecal microbiome in new-onset juvenile idiopathic arthritis. Eur J Clin Microbiol Infect Dis. 2016;35(3):363-70.

5. Giongo A, Gano KA, Crabb DB, Mukherjee N, Novelo LL, Casella G, et al. Toward defining the autoimmune microbiome for type 1 diabetes. ISME J. 2011;5(1):82-91.

6. Murri M, Leiva I, Gomez-Zumaquero JM, Tinahones FJ, Cardona F, Soriguer F, et al. Gut microbiota in children with type 1 diabetes differs from that in healthy children: a case-control study. BMC Med 2013 Feb 21;11:46-7015-11-46.

7. Davis-Richardson AG, Ardissone AN, Dias R, Simell V, Leonard MT, Kemppainen KM, et al. Bacteroides dorei dominates gut microbiome prior to autoimmunity in Finnish children at high risk for type 1 diabetes. Front Microbiol. 2014;5:678.

8. Stoll ML, Kumar R, Morrow CD, Lefkowitz EJ, Cui X, Genin A, et al. Altered microbiota associated with abnormal humoral immune responses to commensal organisms in enthesitis-related arthritis. Arthritis Res Ther. 2014; 16(6):486. -014-0486-0.

9. Cao Y, Shen J, Ran ZH. Association between Faecalibacterium prausnitzii reduction and inflammatory bowel disease: a meta-analysis and systematic review of the literature. Gastroenterol Res Pract. 2014;2014:872725.

10. Koenig JE, Spor A, Scalfone N, Fricker AD, Stombaugh J, Knight R, et al. Succession of microbial consortia in the developing infant gut microbiome. Proc Natl Acad Sci U S A. 2011;108 Suppl 1:4578-85.
11. Bates JM, Mittge E, Kuhlman J, Baden KN, Cheesman SE, Guillemin K. Distinct signals from the microbiota promote different aspects of zebrafish gut differentiation. Dev Biol. 2006;297(2):374-86.

12. Hooper LV, Wong MH, Thelin A, Hansson L, Falk PG, Gordon Jl. Molecular analysis of commensal host-microbial relationships in the intestine. Science. 2001;291(5505):881-4.

13. Rautava S, Luoto R, Salminen S, Isolauri E. Microbial contact during pregnancy, intestinal colonization and human disease. Nat Rev Gastroenterol Hepatol. 2012;9(10):565-76.

14. Biasucci G, Rubini M, Riboni S, Morelli L, Bessi E, Retetangos C. Mode of delivery affects the bacterial community in the newborn gut. Early Hum Dev. 2010;86 Suppl 1:13-5.

15. Huurre A, Kalliomaki M, Rautava S, Rinne M, Salminen S, Isolauri E. Mode of delivery - effects on gut microbiota and humoral immunity. Neonatology. 2008:93(4):236-40.

16. Salminen S, Gibson GR, McCartney AL, Isolauri E. Influence of mode of delivery on gut microbiota composition in seven year old children. Gut. 2004;53(9):1388-9.

17. Dominguez-Bello MG, Costello EK, Contreras M, Magris M, Hidalgo G, Fierer $\mathrm{N}$, et al. Delivery mode shapes the acquisition and structure of the initial microbiota across multiple body habitats in newborns. Proc Natl Acad Sci U S A. 2010;107(26):11971-5.

18. Collado MC, Rautava S, Isolauri E, Salminen S. Gut microbiota: a source of novel tools to reduce the risk of human disease? Pediatr Res. 2015;77(1-2):182-8.

19. Carlens C, Jacobsson L, Brandt L, Cnattingius S, Stephansson O, Askling J. Perinatal characteristics, early life infections and later risk of rheumatoid arthritis and juvenile idiopathic arthritis. Ann Rheum Dis. 2009;68(7):1159-64.

20. Kristensen K, Henriksen L. Cesarean section and disease associated with immune function. J Allergy Clin Immunol. 2015;11.

21. Harmsen HJ, Wildeboer-Veloo AC, Raangs GC, Wagendorp AA, Klijn N, Bindels JG, et al. Analysis of intestinal flora development in breast-fed and formula-fed infants by using molecular identification and detection methods. J Pediatr Gastroenterol Nutr. 2000;30(1):61-7.

22. Montoya J, Matta NB, Suchon P, Guzian MC, Lambert NC, Mattei JP, et al. Patients with ankylosing spondylitis have been breast fed less often than healthy controls: a case-control retrospective study. Ann Rheum Dis. 2015;12

23. Virtanen SM, Rasanen L, Aro A, Lindstrom J, Sippola H, Lounamaa R, et al. Infant feeding in Finnish children less than $7 \mathrm{yr}$ of age with newly diagnosed IDDM. Childhood diabetes in Finland study group. Diabetes Care. 1991;14(5):415-7.

24. Mason T, Rabinovich CE, Fredrickson DD, Amoroso K, Reed AM, Stein LD, et al. Breast feeding and the development of juvenile rheumatoid arthritis. J Rheumatol. 1995;22(6):1166-70.

25. Rosenberg AM. Evaluation of associations between breast feeding and subsequent development of juvenile rheumatoid arthritis. J Rheumatol. 1996;23(6):1080-2.

26. Kasapcopur O, Tasdan Y, Apelyan M, Akkus S, Caliskan S, Sever L, et al. Does breast feeding prevent the development of juvenile rheumatoid arthritis? J Rheumatol. 1998:25(11):2286-7.

27. Jernberg C, Lofmark S, Edlund C, Jansson JK. Long-term ecological impacts of antibiotic administration on the human intestinal microbiota. ISME J. 2007; $1(1): 56-66$

28. Dethlefsen L, Relman DA. Incomplete recovery and individualized responses of the human distal gut microbiota to repeated antibiotic perturbation. Proc Natl Acad Sci U S A. 2011:108 Suppl 1:4554-61.

29. Korpela K, Salonen A, Virta L, Kekkonen RA, Forslund K, Bork P, et al. Intestinal microbiome is related to lifetime antibiotic use in Finnish preschool children. Nat Commun. 2016;7:10410.

30. Horton DB, Scott Fl, Haynes K, Putt ME, Rose CD, Lewis JD, et al. Antibiotic exposure and juvenile idiopathic arthritis: a case-control study. Pediatrics. 2015;136(2):e333-43.

31. Arvonen M, Virta LI, Pokka T, Kroger L, Vahasalo P. Repeated exposure to antibiotics in infancy: a predisposing factor for juvenile idiopathic arthritis or a sign of this Group's greater susceptibility to infections? J Rheumatol. 2015; 42(3):521-6

32. Scher JU, Sczesnak A, Longman RS, Segata N, Ubeda C, Bielski C, et al. Expansion of intestinal Prevotella copri correlates with enhanced susceptibility to arthritis. Elife. 2013;2, e01202.

33. Segain JP. Raingeard de la Bletiere D, Bourreille A, Leray V, Gervois N, Rosales C, et al. Butyrate inhibits inflammatory responses through NFkappaB inhibition: implications for Crohn's disease. Gut. 2000;47(3):397-403. 
34. Sokol H, Pigneur B, Watterlot L, Lakhdari O, Bermudez-Humaran LG, Gratadoux JJ, et al. Faecalibacterium prausnitzii is an anti-inflammatory commensal bacterium identified by gut microbiota analysis of Crohn disease patients. Proc Natl Acad Sci U S A. 2008;105(43):16731-6.

35. Furusawa Y, Obata Y, Fukuda S, Endo TA, Nakato G, Takahashi D, et al. Commensal microbe-derived butyrate induces the differentiation of colonic regulatory T cells. Nature. 2013;504(7480):446-50.

36. Arpaia N, Campbell C, Fan X, Dikiy S, van der Veeken J, DeRoos P, et al. Metabolites produced by commensal bacteria promote peripheral regulatory T-cell generation. Nature. 2013;504(7480):451-5.

37. Rath HC, Herfarth HH, Ikeda JS, Grenther WB, Hamm Jr TE, Balish E, et al. Normal luminal bacteria, especially Bacteroides species, mediate chronic colitis, gastritis, and arthritis in HLA-B27/human beta2 microglobulin transgenic rats. J Clin Invest. 1996;98(4):945-53.

38. Sinkorova Z, Capkova J, Niederlova J, Stepankova R, Sinkora J. Commensal intestinal bacterial strains trigger ankylosing enthesopathy of the ankle in inbred B10.BR (H-2(k)) male mice. Hum Immunol. 2008:69(12):845-50.

39. Zhang X, Zhang D, Jia H, Feng Q, Wang D, Liang D, et al. The oral and gut microbiomes are perturbed in rheumatoid arthritis and partly normalized after treatment. Nat Med. 2015;21(8):895-905.

40. Berntson L, Agback P, Dicksved J. Changes in fecal microbiota and metabolomics in a child with juvenile idiopathic arthritis (JIA) responding to two treatment periods with exclusive enteral nutrition (EEN). Clin Rheumatol. 2016;35(6):1501-6.

41. Kolho KL, Korpela K, Jaakkola T, Pichai MV, Zoetendal EG, Salonen A, et al. Fecal microbiota in pediatric inflammatory bowel disease and its relation to inflammation. Am J Gastroenterol. 2015;110(6):921-30.

42. Ramanan D, Bowcutt R, Lee SC, Tang MS, Kurtz ZD, Ding Y, et al. Helminth infection promotes colonization resistance via type 2 immunity. Science. 2016;352(6285):608-12

43. Bashi T, Shovman O, Fridkin M, Volkov A, Barshack I, Blank M, et al. Novel therapeutic compound tuftsin-phosphorylcholine attenuates collageninduced arthritis. Clin Exp Immunol. 2016;184(1):19-28.

44. Garg SK, Croft AM, Bager P. Helminth therapy (worms) for induction of remission in inflammatory bowel disease. Cochrane Database Syst Rev. 2014;1:CD009400. (1):CD009400.

45. Round $J$, Mazmanian SK. The gut microbiota shapes intestinal immune responses during health and disease. Nat Rev Immunol. 2009;9(5):313-23.

46. Gensollen T, lyer SS, Kasper DL, Blumberg RS. How colonization by microbiota in early life shapes the immune system. Science. 2016;352(6285):539-44.

47. Cahenzli J, Koller Y, Wyss M, Geuking MB, McCoy KD. Intestinal microbial diversity during early-life colonization shapes long-term IgE levels. Cell Host Microbe. 2013;14(5):559-70.

48. Rook GA. Hygiene hypothesis and autoimmune diseases. Clin Rev Allergy Immunol. 2012;42(1):5-15.

49. Olszak T, An D, Zeissig S, Vera MP, Richter J, Franke A, et al. Microbial exposure during early life has persistent effects on natural killer T cell function. Science. 2012;336(6080):489-93.

50. Stoll ML. Gut microbes, immunity, and spondyloarthritis. Clin Immunol. 2015;159(2):134-42.

51. Stebbings S, Munro K, Simon MA, Tannock G, Highton J, Harmsen H, et al. Comparison of the faecal microflora of patients with ankylosing spondylitis and controls using molecular methods of analysis. Rheumatology (Oxford). 2002;41(12):1395-401.

52. Vatanen $T$, Kostic AD, D'Hennezel E, Siljander H, Franzosa EA, Yassour M et al. Variation in microbiome LPS immunogenicity contributes to autoimmunity in humans. Cell. 2016;165(4):842-53.

53. Targan SR, Landers CJ, Yang H, Lodes MJ, Cong Y, Papadakis KA, et al. Antibodies to CBir1 flagellin define a unique response that is associated independently with complicated Crohn's disease. Gastroenterology. 2005; 128(7):2020-8

54. Singh YP, Singh AK, Aggarwal A, Misra R. Evidence of cellular immune response to outer membrane protein of Salmonella typhimurium in patients with enthesitis-related arthritis subtype of juvenile idiopathic arthritis. J Rheumatol. 2011;38(1):161-6.

55. Lange L, Thiele GM, McCracken C, Wang G, Ponder LA, Angeles-Han ST, et al. Symptoms of periodontitis and antibody responses to Porphyromonas gingivalis in juvenile idiopathic arthritis. Pediatr Rheumatol Online J. 2016; 14(1):8. -016-0068-6.

56. Hitchon CA, Chandad F, Ferucci ED, Willemze A, loan-Facsinay A, van der Woude $D$, et al. Antibodies to porphyromonas gingivalis are associated with anticitrullinated protein antibodies in patients with rheumatoid arthritis and their relatives. J Rheumatol. 2010;37(6):1105-12.

57. Feng T, Wang L, Schoeb TR, Elson CO, Cong Y. Microbiota innate stimulation is a prerequisite for $T$ cell spontaneous proliferation and induction of experimental colitis. J Exp Med. 2010;207(6):1321-32.

58. Breban M, Fernandez-Sueiro JL, Richardson JA, Hadavand RR, Maika SD, Hammer RE, et al. T cells, but not thymic exposure to HLA-B27, are required for the inflammatory disease of HLA-B27 transgenic rats. J Immunol. 1996; 156(2):794-803.

59. Taurog JD, Richardson JA, Croft JT, Simmons WA, Zhou M, Fernandez-Sueiro JL, et al. The germfree state prevents development of gut and joint inflammatory disease in HLA-B27 transgenic rats. J Exp Med. 1994;180(6):2359-64.

60. Brandtzaeg P. Function of mucosa-associated lymphoid tissue in antibody formation. Immunol Invest. 2010;39(4-5):303-55.

61. Prindiville TP, Sheikh RA, Cohen SH, Tang YJ, Cantrell MC, Silva Jr J. Bacteroides fragilis enterotoxin gene sequences in patients with inflammatory bowel disease. Emerg Infect Dis. 2000;6(2):171-4.

62. Tailford $L E$, Crost $E H$, Kavanaugh $D$, Juge N. Mucin glycan foraging in the human gut microbiome. Front Genet. 2015;6:81.

63. Derrien M, Vaughan EE, Plugge CM, de Vos WM. Akkermansia muciniphila gen. nov., sp. nov., a human intestinal mucin-degrading bacterium. Int J Syst Evol Microbiol. 2004;54(Pt 5):1469-76.

64. Martinez-Gonzalez O, Cantero-Hinojosa J, Paule-Sastre P, Gomez-Magan JC, Salvatierra-Rios D. Intestinal permeability in patients with ankylosing spondylitis and their healthy relatives. Br J Rheumatol. 1994;33(7):644-7.

65. Mielants H, Veys EM, Cuvelier C, De Vos M, Goemaere S, Maertens M, et al. Gut inflammation in children with late onset pauciarticular juvenile chronic arthritis and evolution to adult spondyloarthropathy-a prospective study. J Rheumatol. 1993;20:1567-72.

66. Lionetti P, Pupi A, Veltroni M, Fonda C, Cavicchi MC, Azzari C, et al. Evidence of subclinical intestinal inflammation by $99 \mathrm{~m}$ technetium leukocyte scintigraphy in patients with HLA-B27 positive juvenile onset active spondyloarthropathy. J Rheumatol. 2000;27:1538-41.

67. Stoll ML, Punaro M, Patel AS. Fecal calprotectin in children with the enthesitis-related arthritis subtype of juvenile idiopathic arthritis. J Rheumatol. 2011;38(10):2274-5.

68. Arvonen M, Vahasalo P, Turunen S, Salo HM, Maki M, Laurila K, et al. Altered expression of intestinal human leucocyte antigen D-related and immune signalling molecules in juvenile idiopathic arthritis. Clin Exp Immunol. 2012; 170(3):266-73.

69. Arvonen M, Ikni L, Augustin M, Karttunen TJ, Vahasalo P. Increase of duodenal and ileal mucosal cytotoxic lymphocytes in juvenile idiopathic arthritis. Clin Exp Rheumatol. 2010;28(1):128-34.

70. Kokkonen J, Arvonen M, Vahasalo P, Karttunen TJ. Intestinal immune activation in juvenile idiopathic arthritis and connective tissue disease Scand J Rheumatol. 2007:36(5):386-9.

71. Pichler J, Ong C, Shah N, Sebire N, Kiparrissi F, Borrelli O, et al. Histopathological features of gastrointestinal mucosal biopsies in children with Juvenile Idiopathic Arthritis. Pediatr Res. 2016;79(6):895-901.

72. De La Cochetiere MF, Durand T, Lepage P, Bourreille A, Galmiche JP, Dore J. Resilience of the dominant human fecal microbiota upon short-course antibiotic challenge. J Clin Microbiol. 2005;43:5588-92.

73. Dethlefsen L, Huse S, Sogin ML, Relman DA. The pervasive effects of an antibiotic on the human gut microbiota, as revealed by deep 165 rRNA sequencing. PLoS Biol. 2008;6, e280.

74. Fouhy F, Guinane CM, Hussey S, Wall R, Ryan CA, Dempsey EM, et al. High-throughput sequencing reveals the incomplete, short-term recovery of infant gut microbiota following parenteral antibiotic treatment with ampicillin and gentamicin. Antimicrob Agents Chemother. 2012;56:5811-20.

75. Jakobsson HE, Jernberg C, Andersson AF, Sjolund-Karlsson M, Jansson JK, Engstrand L. Short-term antibiotic treatment has differing long-term impacts on the human throat and gut microbiome. PLoS One. 2010;5, e9836.

76. Lode H, Von der Hoh N, Ziege S, Borner K, Nord CE. Ecological effects of linezolid versus amoxicillin/clavulanic acid on the normal intestinal microflora. Scand J Infect Dis. 2001;33:899-903.

77. Mangin I, Leveque C, Magne F, Suau A, Pochart P. Long-term changes in human colonic Bifidobacterium populations induced by a 5-day oral amoxicillin-clavulanic acid treatment. PLoS One. 2012;7, e50257.

78. Savino F, Roana J, Mandras N, Tarasco V, Locatelli E, Tullio V. Faecal microbiota in breast-fed infants after antibiotic therapy. Acta Paediatr. 2011;100:75-8. 
79. Vervoort J, Xavier BB, Stewardson A, Coenen S, Godycki-Cwirko M, Adriaenssens $\mathrm{N}$, et al. Metagenomic analysis of the impact of nitrofurantoin treatment on the human faecal microbiota. J Antimicrob Chemother. 2015; 70:1989-92.

80. Lee J, Gonzales-Navajas JM, Raz E. The "polarizing-tolerizing" mechanism of intestinal epithelium: its relevance to colonic homeostasis. Semin Immunopathol. 2008;30(1):3-9.

81. Hooper LV, Macpherson AJ. Immune adaptations that maintain homeostasis with the intestinal microbiota. Nat Rev Immunol. 2010;10(3):159-69.

Submit your next manuscript to BioMed Central and we will help you at every step:

- We accept pre-submission inquiries

- Our selector tool helps you to find the most relevant journal

- We provide round the clock customer support

- Convenient online submission

- Thorough peer review

- Inclusion in PubMed and all major indexing services

- Maximum visibility for your research

Submit your manuscript at www.biomedcentral.com/submit 